\title{
Biochar produced from poultry litter waste
}

\author{
Biochar produzido a partir de resíduos de cama de frango \\ Biocarbón producido a partir de desechos de cama em avicultura
}

Recebido: 22/08/2021 | Revisado: 28/08/2021 | Aceito: 31/08/2021 | Publicado: 04/09/2021

Moisés Edevaldo Pereira
ORCID: https://orcid.org/0000-0002-6065-5995
Federal University of São Carlos, Brazil
Federal Institute of Science and Technology Education of São Paulo, Brazil
E-mail: moisesedevaldo@ hotmail.com
Luciano Donizeti Varanda
ORCID: https://orcid.org/0000-0003-1193-4944
Federal University of São Carlos, Brazil
SENAI Institute for Biomass Innovation, Brazil
E-mail: lu.varanda @hotmail.com
Natália Rodrigues de Carvalho
ORCID: https://orcid.org/0000-0003-2739-2596
Federal University of São Carlos, Brazil
E-mail: n.carvalho084@ @mail.com
Carlos Roberto Sette Jr
ORCID: https://orcid.org/0000-0002-1007-2345
Federal University of Goias, Brazil
E-mail: crsettejr@ hotmail.com
Franciane Andrade de Padua
ORCID: https://orcid.org/0000-0002-3349-8648
Federal University of São Carlos, Brazil
E-mail: franciane@ufscar.br
Andrea Cressoni De Conti
Paulista State University “Júlio de Mesquita Filho”, Brazil
E-mail: andrea.cressoni @unesp.br
Fabio Minoru Yamaji
ORCID: https://orcid.org/000-0002-5433-3295
ORCID: https://orcid.org/0000-0002-0908-8163
Federal University of São Carlos, Brazil
E-mail: fmyamaji @ufscar.br

\begin{abstract}
Brazil generates substantial quantity of poultry litter waste because of its worldwide prominence in the production of broiler chickens. The volume of the poultry litter biomass generates considerable environmental impact. The objective was to characterize the biochar produced from poultry litter residue under different conditions with the aim of determining the best residence time and temperature. Poultry litter was collected after two batches of chicken breeding. Five treatments for biochar production were carried out at a temperature of $450{ }^{\circ} \mathrm{C}$ (defined by thermogravimetric analysis - TGA) and residence times of $0.5,1,2,4$, and $6 \mathrm{~h}$. The biochar produced was assessed using proximate analysis, moisture content, gravimetric yield, scanning electron microscopy (SEM), energy dispersive spectroscopy (EDS), and HHV (higher heating value). The results revealed that the best conditions for biochar production was $450{ }^{\circ} \mathrm{C}$ (pyrolysis) and residence time of $0.5 \mathrm{~h}$, with $37.21 \%$ gravimetric yield. We concluded that the biochar produced in this study is recommended for soil application but was not suitable for energy purposes because of its high ash content (up to 33.66\%) and low $\mathrm{HHV}\left(18,907 \mathrm{~J} \mathrm{~g}^{-1}\right)$.
\end{abstract}

Keywords: Biomass; Residues; Briquettes; Biochar; Poultry litter.

\section{Resumo}

O Brasil produz uma quantidade substancial de resíduo de cama de frango devido a sua proeminência mundial na produção de frangos de corte. $\mathrm{O}$ volume gerado da biomassa de cama de frango gera um impacto ambiental considerável. O objetivo deste estudo foi caracterizar o biochar produzido a partir de resíduos de cama de frango em diferentes condições, com o objetivo de determinar o melhor tempo de residência e temperatura. A cama de frango foi coletada após dois lotes de criação de frangos. Foram realizados 5 tratamentos para a produção do biochar a uma temperatura de $450{ }^{\circ} \mathrm{C}$ (definida pelas análises termogravimétricas - TGA) e tempos de residência de 0,5, 1, 2, 4 e $6 \mathrm{~h}$. O biochar produzido foi analisado através das análises imediatas, rendimento gravimétrico, microscopia eletrônica de varredura (MEV), espectroscopia por energia dispersiva (EDS) e poder calorífico superior (HHV). Os resultados revelaram que as melhores condições para a produção do biochar foram de $450{ }^{\circ} \mathrm{C}$ (temperatura de pirólise) e tempo de residência de 
0,5h, com 37,21\% de rendimento gravimétrico. Concluímos que o biochar produzido neste estudo é recomendado para aplicação no solo, mas não é adequado para fins energéticos devido ao seu elevado teor de cinzas $(33,66 \%)$ e baixo HHV (18.907 J g-1).

Palavras-chave: Biomassa; Resíduos; Briquetes; Biochar; Cama de frango.

\section{Resumen}

Brasil genera una cantidad sustancial de desechos de cama de aves debido a su prominencia mundial en la producción de pollos de engorde. El volumen de la biomasa de la cama em avicultura genera un impacto ambiental considerable. El objetivo fue caracterizar el biocarbón producido a partir de residuos de cama em avicultura en diferentes condiciones con el fin de determinar el mejor tiempo de residencia y temperatura. La basura de las aves se recogió después de dos lotes de cría de pollos. Se realizaron cinco tratamientos para la producción de biocarbón a una temperatura de $450{ }^{\circ} \mathrm{C}$ (definida por análisis termogravimétrico - TGA) y tiempos de residencia de 0.5, 1, 2, 4 y $6 \mathrm{~h}$. El biocarbón producido se evaluó mediante análisis imediata, contenido de humedad, rendimiento gravimétrico, microscopía electrónica de barrido (SEM), espectroscopía de energía dispersiva (EDS) y HHV (valor calorífico superior). Los resultados revelaron que las mejores condiciones para la producción de biocarbón fueron $450^{\circ} \mathrm{C}$ (pirólisis) y un tiempo de residencia de $0,5 \mathrm{~h}$, con un rendimiento gravimétrico del $37,21 \%$. Concluimos que el biocarbón producido en este estudio se recomienda para aplicación al suelo, pero no era adecuado para fines energéticos debido a su alto contenido de cenizas (hasta 33,66\%) y bajo HHV (18,907 J g-1).

Palabras clave: Biomasa; Residuos; Briquetas; Biochar; Cama en avicultura.

\section{Introduction}

Livestock plays an important role in the Brazilian economy; for example, poultry farming is a strongly developed industry in Brazil (Dornelas et al., 2020). Slaughter of 1.55 billion chickens was registered in the first quarter of 2021 (IBGE, 2021). However, it is an industry that produces a large amount of solid waste, such as chicken litter, generating concern regarding waste disposal among poultry farmers (Dornelas et al., 2020; Masud et al., 2020).

Poultry litter, a biomass generated during broiler breeding, mostly reuses agricultural residues such as shavings, peanut shells, rice husks, coffee husks, dry grass, and chopped corn cobs that are generated on the same property (Grimes et al., 2019; Rogeri et al, 2016; Shepherd et al., 2017). According to Garcês et al. (2017), the quantity, and the physical and chemical characteristics of the chicken litter vary depending on several factors, such as the size of the flock, density of the housing (birds per $\mathrm{m}^{2}$ ), number of litter reuses, type of management used, and the environment. In general, poultry litter contains absorbent material such as sawdust, bird excreta, and feathers, in addition to feed and wastewater generated during feeding (Song et al., 2012). The poultry litter quality can affect the productivity of chickens, and the reuse of this residue can generate serious health problems, including the proliferation of pathogenic microorganisms (Benevides et al., 2016; Voss-Rech, 2017) and increased gas emission (de Jong et al., 2016). After exhausting its reuse in the production of chickens, poultry litter residue is traditionally used as a fertilizer because it is rich in nutrients, such as nitrogen $(\mathrm{N})$ and phosphorus $(\mathrm{P})$. However, this practice in excess can cause soil and groundwater contamination resulting from the quantity of organic matter and heavy metals, and the presence of pathogenic microorganisms (Kyakuwaire et al, 2019; Faridullah et al., 2008; Macklin et al., 2008; Kelleher et al., 2002; Siefert et al., 2004).

An alternative is direct burning of the material, which is a viable and environmentally safe method (Masud et al., 2020; Kelleher et al., 2002; Sweeten et al., 2003). To profit from waste and minimize the effects of climate change, bioproducts from biomass can be generated (Usmani et al., 2021; Tripatih et al., 2019). Among the various types of biomasses, animal waste such as poultry litter, has a significant to bioproducts potential (Li et al., 2008; Tanczuk et al., 2019).

In addition, poultry litter has characteristics with potential for biochar production (Pereira et al., 2019). Biochar refers to charcoal produced from biomass that can be applied to the soil. Biochar is a carbon-rich material generated using pyrolysis (Chan et al., 2008), which is a process of thermal degradation in an environment with high temperatures $\left(>250{ }^{\circ} \mathrm{C}\right)$ and an inert atmosphere. According to Masud et al. (2020) and Dai et al. (2017), biochar can be potentially used as a corrective for acidic soils and high aluminum $\left(\mathrm{Al}^{+3}\right)$ levels. 
Although potential exists, the current studies on biochar from poultry litter biomass are limited. The objective of this study was to produce and characterize biochar from poultry litter biomass after two breeding lots.

\section{Methodology}

\subsection{Material}

Poultry litter was collected from a farm located in the city of Quadra-SP that used pinus sawdust on the chicken bed. The farm operates with a chicken bed renewal system after the creation of two batches of chickens (cycle from 90 to 110 days). After the second cycle, the chicken litter compacted, and contained a high moisture content (> 35\%), rendering it impossible to be used to create another batch. The poultry litter was scarified (crushed), lined, collected, and discarded. Approximately $10 \mathrm{~kg}$ of material was collected after the creation of two batches of chickens.

\subsection{Methods}

The methodology used to develop this work was through experimental research, as defined by Pereira, et al. (2018).

\subsubsection{Sample Preparation}

The material was transferred to the laboratory and oven-dried with an air circulation at $60{ }^{\circ} \mathrm{C}$ for $12 \mathrm{~h}$. Subsequently, the material was crushed using a MARCONI Willey knife mill (model MA340), with a 10-mesh sieve.

\subsubsection{Biochar production}

Thermogravimetric analysis (TGA) was performed on the prepared sample using a TGA PERKIN ELMER model Pyris1 analyzer. Three analyses were performed at final temperatures of 300,450 , and $750{ }^{\circ} \mathrm{C}$, under a nitrogen atmosphere $(20$ $\mathrm{ml} \mathrm{min}$ ), heating rate of $20^{\circ} \mathrm{C} \mathrm{min}^{-1}$, and residence time of $60 \mathrm{~min}$. The purpose of these analyses (TGA) was to establish the optimum final temperature for biochar production.

\subsubsection{Treatments}

After defining the optimum temperature, five treatments were performed to produce the biochar at a temperature of 450 ${ }^{\circ} \mathrm{C}$ and with the following residence times: $0.5 \mathrm{~h}$ (T1); $1 \mathrm{~h}$ (T2); $2 \mathrm{~h}$ (T3); $4 \mathrm{~h}$ (T4) and $6 \mathrm{~h}$ (T5).

For pyrolysis, the crucibles were completely filled with poultry litter residue $( \pm 12 \mathrm{~g})$, to ensure maximum oxygen removal. They were subsequently covered and the treatments for biochar production were performed in a JUNG muffle furnace (model LF00212) at a heating rate of $20^{\circ} \mathrm{C} \mathrm{min}^{-1}$. All treatments and analyzes were performed in triplicates.

\subsubsection{Moisture content}

The moisture content in the produced biochar using different residence time was determined using a MARCONI moisture scale (model ID200). The results were obtained on a dry basis.

\subsubsection{Gravimetric Yield}

The gravimetric yield of the biochar obtained at different residence time was determined using Equation 1:

$r g=\frac{\mathrm{mf}}{\mathrm{mi}} * 100$

Where: 
$\mathrm{rg}=$ gravimetric yield $(\%)$,

$\mathrm{mi}=$ initial mass of chicken litter $(\mathrm{g})$,

$\mathrm{mf}=$ final biochar mass $(\mathrm{g})$

\subsubsection{Proximate Analysis}

Proximate analyses (volatile, ash, and fixed carbon contents) were conducted for the biochar produced at different residence times, according to ASTM D1762-84. Analyses were performed using dry samples. The crucibles and lids were calcined in a muffle furnace at $600{ }^{\circ} \mathrm{C}$ for $15 \mathrm{~min}$.

\section{Volatile matter}

To determine the volatile matter, 1 to $2 \mathrm{~g}$ of the biochar material was weighed. The muffle furnace was heated to 950 ${ }^{\circ} \mathrm{C}$, and the crucibles were placed in the (open) door of furnace muffle for $2 \mathrm{~min}$. Then, the crucibles were transferred into the oven, with the door open for $3 \mathrm{~min}$. Finally, the muffle door was closed and maintained for another 6 min.

After this procedure, the crucibles were cooled in a desiccator for $1 \mathrm{~h}$ and weighed.

The volatile matter was determined according to Equation 2:

$t v=\frac{(\mathrm{mi}-\mathrm{mf})}{\mathrm{mi}} * 100$

Where:

$\mathrm{tv}=$ volatile matter $(\%)$,

$\mathrm{mi}=$ initial mass $(\mathrm{g})$,

$\mathrm{mf}=$ final mass $(\mathrm{g})$.

\section{Ash Content}

For the determination of ash content, approximately 1 to $2 \mathrm{~g}$ of the material was used and placed in a pre-weighed crucible. The crucibles without a lid were placed in the muffle furnace at a temperature of $750{ }^{\circ} \mathrm{C}$ for $6 \mathrm{~h}$, and subsequently cooled in a desiccator for $1 \mathrm{~h}$ and weighed. The process was repeated at the same temperature for $1 \mathrm{~h}$. Then, the samples were cooled in a desiccator and re-weighed. As the final mass remained unchanged, a cycle was concluded.

The ash content was determined using Equation 3:

$t c=\frac{\mathrm{mf}}{\mathrm{mi}} * 100$

Where:

tc $=$ ash content $(\%)$,

$\mathrm{mi}=$ initial mass $(\mathrm{g})$,

$\mathrm{mf}=$ final mass $(\mathrm{g})$.

\section{Fixed Carbon}

The determination of the fixed carbon content was in accordance with Equation 4: 
$t c f=100-(\mathrm{tc}+\mathrm{tv})$

Where:

$\mathrm{tcf}=$ fixed carbon content $(\%)$,

tc $=$ ash content $(\%)$,

$\mathrm{tv}=$ volatile content $(\%)$.

\section{Higher Heating Value}

The analysis of the higher heating value (HHV) of the biochar was performed using a calorimeter IKA model C200. The dry samples were weighed (approximately 500 to $600 \mathrm{mg}$ ) in an analytical balance (SHIMADZU, model AUY220). The sample was inserted into a calorimetric pump and filled with oxygen $(99,99 \%)$ at a pressure of 30 bar.

\subsubsection{Scanning Electron Microscopy (SEM) / Energy Dispersive Spectroscopy (EDS)}

The produced biochars were analyzed using SEM and EDS. The values were collected at various points in each sample. The values (\%) of the biochar components were obtained from the average of these points for each material. The equipment used for the analyses was the HITACHI, model TM3000.

\subsubsection{Statistical Analysis}

Analysis of variance (ANOVA) and Tukey's test (for comparison of means) were performed for all analyses.

\section{Results and discussion}

\subsection{Biochar treatments}

Table 1 shows the products of the different types of pyrolysis of carbonization of biomass under a range of low (400 to $\left.450{ }^{\circ} \mathrm{C}\right)$, moderate $\left(450\right.$ to $\left.500^{\circ} \mathrm{C}\right)$, and high $\left(900{ }^{\circ} \mathrm{C}\right)$ temperatures.

Table 1. Products of the different types of pyrolysis

\begin{tabular}{llccc}
\hline \multicolumn{1}{c}{ Type of pyrolysis } & \multicolumn{1}{c}{$\begin{array}{c}\text { Temperatures } \\
\left({ }^{\mathbf{C}}\right)\end{array}$} & Liquid (\%) & $\begin{array}{c}\text { Charcoal / solid } \\
(\boldsymbol{\%})\end{array}$ & $\begin{array}{c}\text { Gas } \\
(\boldsymbol{\%})\end{array}$ \\
\hline Carbonization & Low (400-450) & 30 & $\mathbf{3 5}$ & 35 \\
Fast pyrolysis & Moderates (450-500) & 75 & 12 & 13 \\
Gasification & High (900) & 5 & 10 & 85 \\
\hline
\end{tabular}

Source: Adapted from Bridgwater et al. (2008).

To obtain the maximum yield, an appropriate method must be selected for the biomass characteristics and process conditions (heating rate, temperature, and residence time). The process conditions also influence the physical and chemical properties of biochar, as well as its morphology. In the pyrolysis process, as the temperature range increased, the percentage of charcoal decreased (Padilla et al., 2019; Yaashika et al., 2020).

Table 1 shows that to obtain the highest yield of the solid portion (35\% of charcoal), the ideal temperature should range between $400-450{ }^{\circ} \mathrm{C}$. Therefore, thermogravimetric analysis (TGA) was performed to confirm these data.

Thermogravimetric analyses, with final temperatures at 300, 450, and $750{ }^{\circ} \mathrm{C}$, are shown in Figure 1. 
Figure 1. Thermogravimetric analyses of poultry litter pyrolysis: final temperatures of (A) $300{ }^{\circ} \mathrm{C}$; (B) $450{ }^{\circ} \mathrm{C}$; (C) $750{ }^{\circ} \mathrm{C}$.
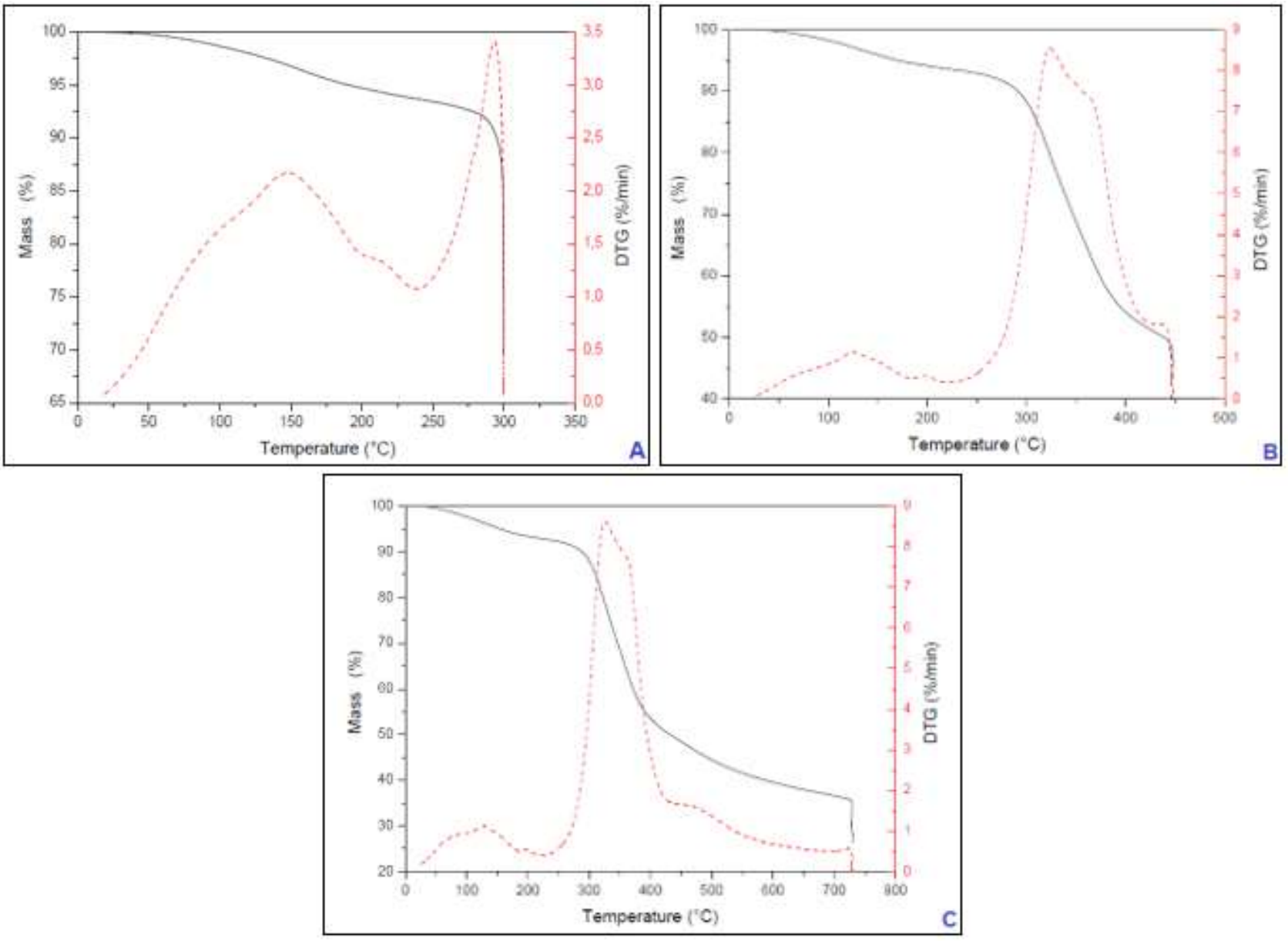

Source: Authors.

Figure 1 shows that the peak of degradation occurred at approximately $320^{\circ} \mathrm{C}$ in samples, as shown in figures $1 \mathrm{~B}(450$ $\left.{ }^{\circ} \mathrm{C}\right)$ and $1 \mathrm{C}\left(750^{\circ} \mathrm{C}\right)$. According to Wang et al. (2017), water loss begins at approximately $100^{\circ} \mathrm{C}$. Subsequently, with an increase in temperature, the weight is reduced likely due to the start degradation of hemicellulose at temperatures above $200{ }^{\circ} \mathrm{C}$. The final mass at $450{ }^{\circ} \mathrm{C}(1 \mathrm{~B})$ and $750{ }^{\circ} \mathrm{C}(1 \mathrm{C})$ was approximately $50 \%$ and $35 \%$. Figure $1 \mathrm{~A}$ shows that the peak of degradation was approximately $290{ }^{\circ} \mathrm{C}$, with a final mass of $85 \%$. The final temperature of $300{ }^{\circ} \mathrm{C}$ was insufficient for biomass degradation. Pyrolysis at $300{ }^{\circ} \mathrm{C}$ was not ideal for chicken-bed biochar.

Significant thermal degradation occurred at a temperature between $300{ }^{\circ} \mathrm{C}$ and $450{ }^{\circ} \mathrm{C}$, as observed in both figures (1B and $1 \mathrm{C}$ ). Above $450{ }^{\circ} \mathrm{C}$, the percentage of degradation was approximately $10 \%$, which does not justify energy expenditure. For example, at $750{ }^{\circ} \mathrm{C}$, the degradation was relatively small after the maximum thermal degradation temperature $\left(450{ }^{\circ} \mathrm{C}\right)$. Thus, $450{ }^{\circ} \mathrm{C}$ was considered the optimal temperature for the production of poultry litter biochar.

Some studies also corroborate the ideal temperature of $450{ }^{\circ} \mathrm{C}$ for biomass pyrolysis. The pyrolysis for charcoal production is often conducted at temperatures of approximately $450^{\circ} \mathrm{C}\left(<500{ }^{\circ} \mathrm{C}\right)$ (Padilla et al., 2019).

The pyrolysis temperature was also an important factor in determining the water retention capacity of soil. Studies have revealed an enhancement in water infiltration in the soil after adding cotton biochar produced at $600{ }^{\circ} \mathrm{C}$ (Speratti et al., 2017). Besides, the study of Chen et al. (2021), showed that the adsorption capacity of biochar produced at $450{ }^{\circ} \mathrm{C}$ were improved. According to Domingues et al. (2017), biochar produced at low temperatures $\left(450^{\circ} \mathrm{C}\right)$ also showed high cation exchange capacity 
(CEC) values $\left(21.3 \mathrm{cmol}_{\mathrm{c}} \mathrm{kg}^{-1}\right)$ and an increase in pyrolysis temperature from $450{ }^{\circ} \mathrm{C}$ to $750{ }^{\circ} \mathrm{C}$ reduced the biochar $\mathrm{CEC}$ values. Thus, in this study, the temperature adopted for biochar production was $450{ }^{\circ} \mathrm{C}$.

\subsection{Moisture Content, Gravimetric Yield, Proximate Analysis and Higher Heating Value (HHV)}

Table 2 shows the moisture content, gravimetric yield, Proximate Analysis and Higher Heating Value of biochar treatments.

Table 2. Moisture content gravimetric yield, Proximate Analysis and Higher Heating Value of the biochar treatments produced $\left(450{ }^{\circ} \mathrm{C}\right)$.

\begin{tabular}{ccccccc}
\hline Treatments & $\begin{array}{c}\text { Moisture } \\
\text { content }(\boldsymbol{\%})\end{array}$ & $\begin{array}{c}\text { Gravimetric } \\
\text { Yield }(\boldsymbol{\%})\end{array}$ & $\begin{array}{c}\text { Volatile matter } \\
(\boldsymbol{\%})\end{array}$ & $\begin{array}{c}\text { Ash content } \\
(\boldsymbol{\%})\end{array}$ & $\begin{array}{c}\text { Fixed Carbon } \\
(\boldsymbol{\%})\end{array}$ & HHV $\left(\mathbf{J ~ g} \mathbf{g}^{-1}\right)$ \\
\hline T1 (0.5h) & $4.3(0.10) \mathrm{a}$ & $37.21(0.12) \mathrm{a}$ & $23.13(0.47) \mathrm{a}$ & $33.66(1.44) \mathrm{a}$ & $43.19(0.97) \mathrm{a}$ & $18,907(0.02) \mathrm{a}$ \\
T2 (1h) & $3.3(0.15) \mathrm{b}$ & $36.74(0.23) \mathrm{b}$ & $21.49(0.13) \mathrm{b}$ & $37.94(0.69) \mathrm{b}$ & $40.55(0.76) \mathrm{a}$ & $18,968(0.05) \mathrm{a}$ \\
T3 (2h) & $2.9(0.25) \mathrm{c}$ & $36.11(0.01) \mathrm{c}$ & $15.88(0.50) \mathrm{c}$ & $38.92(0.67) \mathrm{c}$ & $45.19(0.55) \mathrm{a}$ & $19,030(0.07) \mathrm{a}$ \\
T4 (4h) & $2.1(0.25) \mathrm{d}$ & $35.41(0.19) \mathrm{d}$ & $13.81(0.49) \mathrm{d}$ & $45.59(1.33) \mathrm{d}$ & $43.59(1.00) \mathrm{a}$ & $18,951(0.31) \mathrm{a}$ \\
T5 (6h) & $1.4(0.20) \mathrm{e}$ & $32.45(0.05) \mathrm{e}$ & $12.09(0.25) \mathrm{e}$ & $53.79(2.50) \mathrm{e}$ & $34.10(2.57) \mathrm{b}$ & $16,852(0.06) \mathrm{b}$ \\
\hline
\end{tabular}

Source: Authors.

The values in the table represent the treatment mean and the values in parentheses represent \pm standard deviation. Different letters in the same column indicate a significant difference between the values at the $95 \%$ level of significance by Tukey's test.

\subsubsection{Moisture Content and Gravimetric Yield}

The results showed that all biochar produced had a low moisture content $(<4.3 \%)$.

As expected, the gravimetric yield decreased with increasing residence time of the treatments. The gravimetric yield of the biochar in this study was higher (between $32 \%$ and 37\%) than that of the biochar of other biomasses from previous studies. The gravimetric yield of agricultural waste (including date leaves and other lawn wastes such as ornamental plants residues, grass clippings and coconut leaves), was $24 \%$ when produced at $450{ }^{\circ} \mathrm{C}$ with residence time of $3 \mathrm{~h}$ (Waqas et al., 2018). Additionally, for biochar from the hybrid Eucalyptus grandis x Eucalyptus urophylla, a 25\% yield was observed at a temperature of $450^{\circ} \mathrm{C}$ and residence time of $4 \mathrm{~h}$ (da Róz et al., 2015). According to the literature, solid animal residues exhibit higher biochar yield when compared to forest and agricultural biomass (Yaashika et al., 2020), as in the present study. This can be explained by the high ash content in animal residues (manure) compared to forest biomass. Based on the results of the gravimetric yield, it can be deduced that the best treatment time was $0.5 \mathrm{~h}$ (T1) (highest yield).

\subsubsection{Proximate Analysis and Higher Heating Value (HHV)}

As expected, the volatile content decreased with increasing residence time. The ash content also behaved as expected with the residence time; the degradation of the material resulted in a high ash content (33.66 to 53.79\%). In general, the ash content of the wood is <1\% (de Carvalho et al., 2020; da Silva et al., 2018). The high values of the ash content are related to the impurities in the material (Padilla et al., 2019). Milling, heaping, and loading occurs when the poultry litter is collected from the farm. During these operations, the particles from the farm floor such as soil and sand are dragged along. 
The analyses of fixed carbon content and HHV indicated that the treatments at $0.5,1,2$, and $4 \mathrm{~h}$ did not differ statistically; that is, although the yield varied at each residence time, the amount of available carbon for burning and the HHV did not vary. The $6 \mathrm{~h}$ treatment differed from the others in all aspects. The lower value of fixed carbon content and lower HHV in the $6 \mathrm{~h}$ treatment (T5) is related to higher ash content $(53.79 \%)$.

The HHV was considered low in all treatments. All the produced biochar presented values similar to the HHV of fresh biomass, such as the olive core $\left(19,000 \mathrm{~J} \mathrm{~g}^{-1}\right)$, almond shell $\left(18,800 \mathrm{~J} \mathrm{~g}^{-1}\right)$, and hazelnut shell (19,300 J g $\left.\mathrm{g}^{-1}\right)$ (Demirbas et al., 2006). The low values can be justified by the high ash content (> 30\%) in all treatments. The HHV indicated that chicken bed biochar is not ideal for energy purposes. However, for soil application, the HHV for biochar is not a determining factor.

The fixed carbon content was slightly lower $(\mathrm{T} 1=43.19 \%$ and $\mathrm{T} 5=34.10 \%)$ compared to the to wheat straw biochar, for example, where a value of $52 \%$ was observed with biochar treated at $400{ }^{\circ} \mathrm{C}$ with a residence time of $2 \mathrm{~h}$ (Junna et al., 2016). Also, Padilla et al. (2019) produced charcoal from eucalyptus bark and the fixed carbon was $47 \%$ (400 $\left.{ }^{\circ} \mathrm{C}\right)$ with a residence time of $3 \mathrm{~h}$. The lower values for fixed carbon in this study can be explained by high ash content $(\mathrm{T} 1=33.66 \%$ and $\mathrm{T} 5=53.79 \%)$.

The high gravimetric yield, low HHV, and low fixed carbon content can be explained by the high ash content of the material. Ash is the mineral part of the material (not carbonized) that remains in the combustion process. As a result, the high gravimetric yield of biochar production is due to ash. These results enable the application of the produced biochar into the soil.

\subsection{Scanning Electron Microscopy (SEM) / Energy Dispersive Spectroscopy (EDS)}

Characterization of biochar via structural and elemental analyses, using techniques such as scanning electron microscopy (SEM), help to predict the behavior of biochar in various applications, such as adsorption, and removal of pollutants from the soil (Yaashika et al., 2020; Pariyar et al., 2020; Brewer et al., 2014), and availability of nutrients to plants (Lin et al, 2013). Table 3 presents the elements contained in the different biochar treated sample obtained by energy dispersive spectroscopy (EDS). The norm. C [wt. \%] column, refers to the normalized concentration of the element in the mass percentage.

Table 3. List of elements obtained by Energy Dispersive Spectroscopy (EDS) of the different biochar treatments.

\begin{tabular}{lccccc}
\hline \multirow{1}{*}{ Element } & $\mathbf{0 . 5 h}$ & $\mathbf{1 h}$ & $\mathbf{2 h}$ & $\mathbf{4 h}$ & $\mathbf{6 h}$ \\
\cline { 2 - 6 } & & & norm. C [wt. \%] & & 36.25 \\
\hline Potassium & 37.31 & 36.50 & 36.43 & 16.86 & 20.52 \\
Calcium & 20.06 & 17.04 & 17.70 & 16.46 & 10.37 \\
Chlorine & 13.36 & 16.98 & 16.94 & 7.30 & 7.87 \\
Sodium & 6.95 & 6.37 & 6.06 & 5.22 & 8.86 \\
Phosphor & 5.26 & 5.17 & 5.07 & 4.80 & 6.25 \\
Sulfur & 5.06 & 4.66 & 4.72 & 4.16 & 3.31 \\
Silicon & 3.61 & 4.16 & 4.59 & 3.23 & 5.68 \\
Magnesium & 3.18 & 3.01 & 3.18 & 2.87 & 3.02 \\
Aluminum & 2.68 & 2.99 & 2.78 & 2.84 & 3.15 \\
Iron & 2.52 & 3.13 & 100.00 & 100.00 & 100.00 \\
\hline Total & 100.00 & 100.00 & & & \\
\hline
\end{tabular}


The quantitative analysis performed using EDS allowed a comparative analysis of the elements.

Potassium was the most abundant element. The presence of potassium is plausible since it is, after nitrogen, the most absorbed element by corn (Barzan et al., 2021; Parente et al., 2016). Corn is the main ingredient used in chicken feed.

Calcium is vital for the development of plants; it functions in the cell wall and is crucial for the germination of seeds and helps reduce soil acidity (Liu et al., 2011).

The silicon present in the treatments was due to the impurities from the contact of the poultry litter with the soil.

The iron content in the biochar samples is probably related to the use of these elements in the composition of the birds' feed (Vieites et al, 2015). Values of iron contained in the biochar were similar to the value found in the poultry litter with the creation of two batches (2.54\%) (Pereira et al., 2019).

The presence of sodium in the treatments helps to maintain the soil $\mathrm{pH}$, rendering it more alkaline. Sodium is important for plants because it controls the osmotic pressure in the cells that assists in efficient use of water (Katsuhara et al., 2011).

In all treatment samples, whitish fragments were observed on the surfaces of the biochar particles (Figure 2).

Figure 2. Presence of potassium chloride.
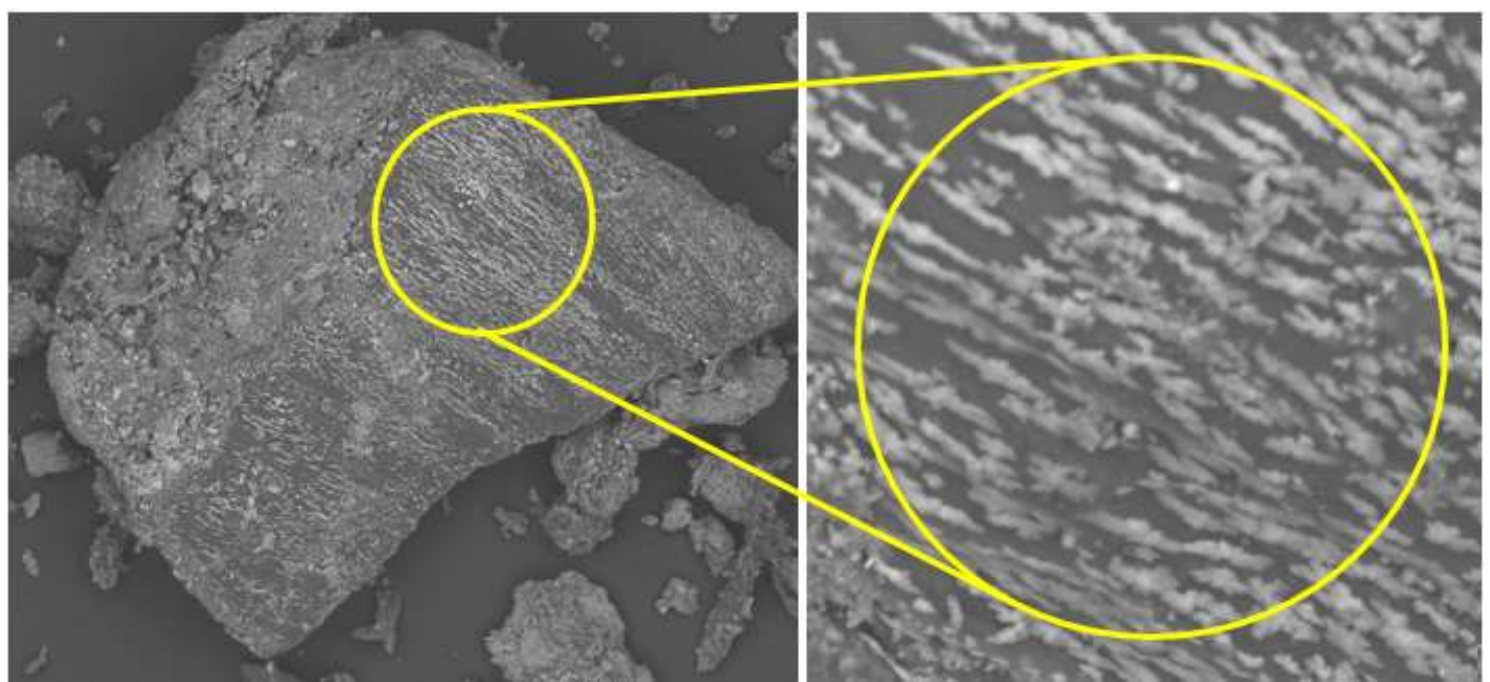

Source: Authors.

Figure 2 shows the potassium chloride concentration. The whitish parts are potassium chloride, which explains the high concentrations of chlorine and potassium in the samples.

The other elements in considerable concentrations were phosphorus and sulfur. Phosphorus is an essential nutrient for plants, functioning as a catalyst in several important biochemical reactions in plants. Sulfur and magnesium are also important in agriculture. Sulfur has functions, among others, of assisting the plant in its defense against pests, and in hormonal control for cell growth and differentiation. Magnesium is an important component of chlorophyll and helps fix carbon in the soil (Guo et al., 2016).

Porosity is another characteristic of biochar. Table 4 shows the classification of pores according to the International Union of Pure and Applied Chemistry (IUPAC). 
Table 4. Classification of pores according to IUPAC.

\begin{tabular}{cc}
\hline Classification & Pore size \\
\hline Micropore & diameter $<2 \mathrm{~nm}$ \\
Mesopore & $2 \mathrm{~nm}<$ diameter $<50 \mathrm{~nm}$ \\
Macropore & diameter $>50 \mathrm{~nm}$ \\
\hline
\end{tabular}

Source: Adapted from Zdravkov et al. (2017).

According to Table 4, pores with diameters greater than $50 \mathrm{~nm}$ are considered macropores. The presence of macropores (Figure 3) was evident, with a diameter of approximately 5 to $10 \mu \mathrm{m}$ (highlighted in yellow), and approximately $1 \mu \mathrm{m}$ in diameter (highlighted in red) in the biochar samples.

Figure 3 shows the porosity in the biochar in different size scales.

Figure 3. Porosity of the biochar.
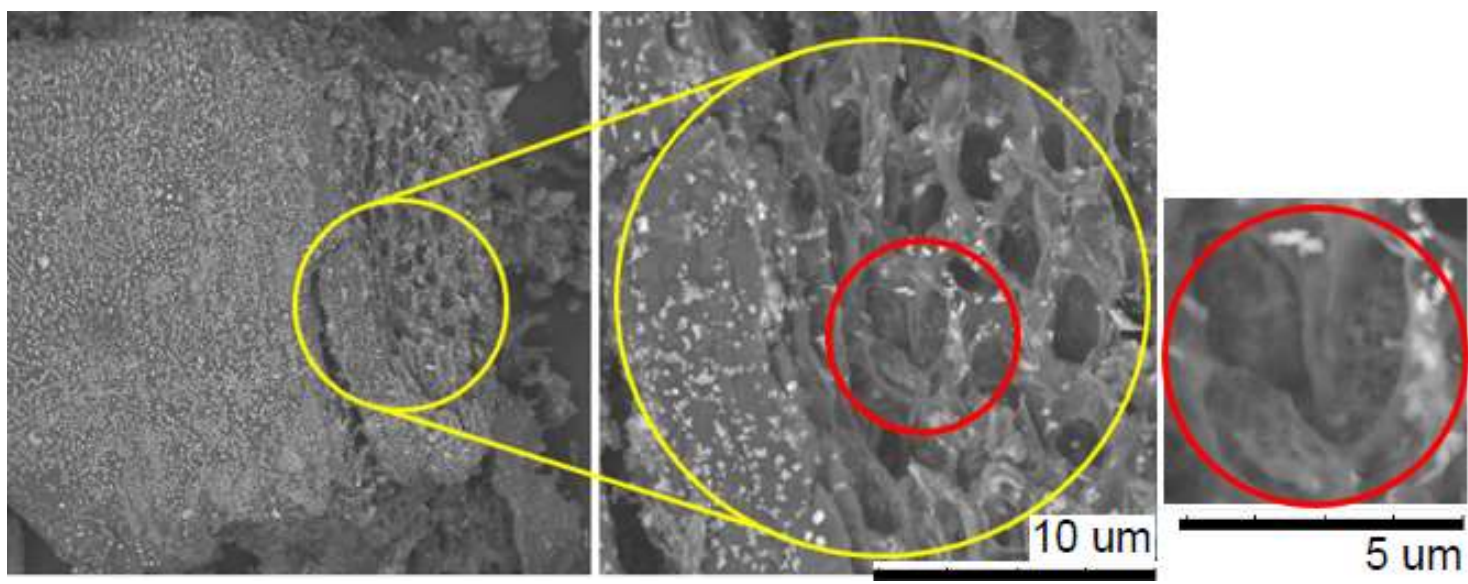

Source: Authors.

Macroporosity is an important feature of biochar, as it feeds mesopores and micropores in fluid transport, making biochar an important adsorbent material (Yu et al., 2020).

The porosity of biochar has the potential to improve the physical, chemical, and biological properties of soils (Lehmann et al., 2011).

However, biochar porosity has many aspects that remain unclear, which needs to be investigated; for example, the effect of particle size of the biochar on the structure of macropores (Yu et al., 2020). In addition, the effect of porosity (biochar), particle size (biochar), and soil porosity needs to be studied.

\section{Conclusion}

The chicken litter can be used to produce biochar.

$\mathrm{T} 1$ treatment $\left(0.5 \mathrm{~h}\right.$ and $\left.450{ }^{\circ} \mathrm{C}\right)$ can be considered the best treatment.

The T1 (0.5h), T2 (1h), T3 (2h), and T4 (4h) treatments did not show statistically significant differences in the fixed carbon content, indicating that treating for $0.5 \mathrm{~h}$ was sufficient to ensure the stability of the biochar.

The T5 treatment (6h) indicated that time must be controlled to avoid loss of productivity. 
Chicken bed biochar is unsuitable for energy purposes because it presents a relatively low HHV, mainly due to its high ash content (> 30\%). However, these characteristics are not limiting factors for soil application.

Hence, the biochar produced from poultry litter appears suitable for soil application.

The next step will be the study of blends of chicken litter with biomass not suitable for energy (eucalyptus bark, sugarcane straw). Blends can increase the supply of raw material for the continuous production of biochar.

\section{References}

ASTM D1102-84, Standard Test Method for Ash in Wood (2021). ASTM International, http://www.astm.org/Standards/D1102.

Barzan, R. R., Jordão, L. T., Firmano, R. F., Secato, T. R., Lima, F., Barzan, L. R., de Oliveira Jr., A., Castro, C., Crusciol, C. A. C., \& Zucareli, C. (2021). Soil chemical attributes and nutritional status of soybean and maize intercropped with Urochloa under nitrogen rates. Agronomy Journal, 11, https://doi.org/10.1002/agj2.20744.

Benevides, W. S., Díaz, M. P., Guano, L. E., Pinheiro, A. R. A., Frota, L. O., Campos, W. O., \& Pinto, P. W. C. (2016). Study of animal welfare through analysis and comparison of the presence of foot pad dermatitis in broilers raised in controlled environments in Brazil and Spain. Revista Brasileira de Higiene e Sanidade Animal, 10, 330-350, https://dx.doi.org/10.5935/1981-2965.20160028.

Brewer, C. E., Chuang, V. J., Masiello, C. A., Gonnermann, H., Gao, X., Dugan, B., Driver, L. E., Panzacchi, P., Zygourakis, K., \& Davies, C. A. (2014). New approaches to measuring biochar density and porosity. Biomass and Bioenergy, 66, 176-185, https://doi.org/10.1016/j.biombioe.2014.03.059.

Bridgwater, A. V., Czernik, S., \& Piskorz, J. (2001). Chapter 80 - An overview of fast pyrolysis. In - Progress in thermochemical biomass conversion. Blackwell Science Ltd., 977-997, https://doi.org/10.1002/9780470694954.ch80.

Chan, K. Y., van Zwieten, L., Meszaros, I., Downie, A., \& Joseph, S. (2008). Using poultry litter biochars as soil amendments. Australian Journal of Soil Research, 46, 437-444, https://doi.org/10.1071/SR08036.

Chen, Y., Xu, Q., Sun, K., Han, L., Sun, H., Yang, Y., \& Wang, Z. (2021). Effects of simulated diagenesis and mineral amendment on the structure, stability and imidacloprid sorption properties of biochars produced at varied temperatures. Chemosphere, 282, 121-003, https://doi.org/10.1016/j.chemosphere.2021.131003.

da Róz, A. L., Ricardo, J. F. C., Nakashima, G. T., \& Santos, L. R. O., Yamaji, F. M. (2015). Maximization of fixed carbon content in biochar applied to carbon sequestration. Rev. Bras. Eng. Agríc. Ambient., 19, 810-814, https://doi.org/10.1590/1807-1929/agriambi.v19n8p810-814.

da Silva, C. J. \& do Vale, A. T. (2018). Energy density model for forest species from cerrado. Rev. Caatinga, 31, 396-404. https://doi.org/10.1590/1983$21252018 \mathrm{v} 31 \mathrm{n} 216 \mathrm{rc}$.

Dai, Z., Zhang, X., Tang, C., Muhammad, N., Wu, J., Brookes, P. C., \& Xu, J. (2017). Potential role of biochars in decreasing soil acidification - a critical review. Science of The Total Environment, 581-582, 601-611, https://doi.org/10.1016/j.scitotenv.2016.12.169.

de Carvalho, N. R., de Barros, J. L., da Silva, D. A., Nakashima, G. T., \& Yamaji, F. M. (2020). Physical an chemical characterization of biomass used as solid fuel in a boiler. Química Nova, 10, 35-40, https://dx.doi.org/10.21577/0100-4042.20170663.

de Jong, I. C., Hindle, V. A., Butterworth, A., Engel, B., Ferrari, P., Gunnink, H., Perez Moya, T., Tuyttens, F. A. M., \& van Reenen, C. G. (2016). Simplifying the Welfare Quality® assessment protocol for broiler chicken welfare. Animal, 10, 117-127, https://doi.org/10.1017/S1751731115001706.

Demirbas, A. (2006). Effect of temperature on pyrolysis products from four nut shells. J. Anal. Appl. Pyrolysis, 76, 285-289, https://doi.org/10.1016/j.jaap.2005.12.012.

Domingues, R. R., Trugilho, P. F., Silva, C. A., de Melo, I. C. N. A., Melo, L. C. A., Magriotis, Z. M., \& Sánches-Monedero, M. A. (2017). Properties of biochar derived from wood and high-nutrient biomasses with the aim of agronomic and environmental benefits. Journal Plos One, 12, 176-884, https://doi.org/10.1371/journal.pone.0176884.

Dornelas, K. C., Mascarenhas, H. N. M., Rodrigues, H. C. S., Nascimento, R. T., Brito, A. N. S., Furtado, D. A., \& Nascimento, J. W. B. (2020). Withdrawn: Chicken bed: a review on reuse, treatment and influence on ambience. Poultry Science., https://doi.org/10.1016/j.psj.2020.09.067.

Faridullah, F., Yamamoto, S., Irshad, M., Uchiyama, T., \& Toshimasa, H. (2008). Phosphorus fractionation in chicken and duck litter burned at different temperatures. Soil Science., 173, 287-295, http://dx.doi.org/10.1097/SS.0b013e31816d1e5b.

Garcês, A. P. T. J., Afonso, S. M. S., Chilundo, A., \& Jairoce, C.T. S. (2017). Evaluation of different litter materials for broiler production in a hot and humid environment: 2. Productive performance and carcass characteristics. Tropical Animal Health Production, 49, 369-374, https://doi.org/10.1007/s11250-016-12027 .

Grimes, J. L., Smith, J., \& Williams, C. M. (2019). Some alternative litter materials used for growing broilers and turkeys. World's Poultry Science Journal, 58 515-526, https://doi.org/10.1079/WPS20020037.

Guo, W., Nazim, H., Liang, Z., \& Yang, D. (2016). Magnesium deficiency in plants: an urgent problem, The Crop Journal, 4, 83-91, https://doi.org/10.1016/j.cj.2015.11.003. 
IBGE - Brazilian Institute of Geografy and Statistics, Livestock production statistics: Initial results (2021). IBGE, https://biblioteca.ibge.gov.br/visualizacao/periodicos/3087/epp_pr_2021_1tri.pdf.

Junna, S., He, F., Pan, Y., \& Zhang, Z. (2016). Effects of pyrolysis temperature and residence time on physicochemical properties of different biochar types. Acta Agriculturae Scandinavica, Section B - Soil \& Plant Science, 67, 12-22, https://doi.org/10.1080/09064710.2016.1214745.

Katsuhara, M., Rhee, J. Y., Sugimoto, G., \& Chung, G. C. (2011). Early response in water relations influenced by NaCl reflects tolerance or sensitivity of barley plants to salinity stress via aquaporins. Soil Science and Plant Nutrition, 57, 50-60, https://doi.org/10.1080/00380768.2010.541870.

Kelleher, B. P., Leahy, J. J., Henihan, A. M., O'Dwyer, T. F., Sutton, D., \& Leahy, M. J. (2002). Advances in poultry litter disposal technology - a review, Bioresource Technology, 83, 27-36, https://doi.org/10.1016/s0960-8524(01)00133-x.

Kyakuwaire, M., Olupot, G., Amoding, A., Nkedi-Kizza, P., \& Basamba, T. A. (2019). How safe is chicken litter for land application as an organic fertilizer?: A review. Int. J. Environ. Res. Public Health, 16, 3521, https://doi.org/10.3390/ijerph16193521.

Lehmann, J., Rillig, M. C., Thies, J., Masiello, C. A., Hockaday, W. C., \& Crowley, D. (2011). Biochar effects on soil biota - a review. Soil Biology and Biochemistry, 43, 1812-1836, https://doi.org/10.1016/j.soilbio.2011.04.022.

Li, S., Wu, A., Deng, S., \& Pan, W. (2008). Effect of co-combustion of chicken litter and coal on emissions in a laboratory-scale fluidized bed combustor. Fuel, Processing Technology., 89, 7-12, https://doi.org/10.1016/j.fuproc.2007.06.003.

Lin, Y., Munroe, P., Joseph, S., Ziolkowski, A., van Zwieten, L., Kimber, S., \& Rust, J. (2013). Chemical and structural analysis of enhanced biochars: Thermally treated mixtures of biochar, chicken litter, clay and minerals. Chemosphere, 91, 35-40, https://doi.org/10.1016/j.chemosphere.2012.11.063.

Liu, T., Wu, F., Wang, W., Chen, J., Li, Z., Dong, X., Patton, J., Pei, Z., \& Zheng, H. (2011). Effeccts of calcium on seed germination, seedling growth and photosynthesis of six forest tree species under simulated acid rain. Tree Physiology, 31, 402-413, https://doi.org/10.1093/treephys/tpr019.

Macklin, K. S., Hess, J. B., \& Bilgili, S. F. (2008). In-house windrow composting and its effects on foodborne pathogens. Journal of Applied Poultry Ressearch, 17, 121-127, https://doi.org/10.3382/japr.2007-00051.

Masud, M. M., Baquy, M. A., Akhter, S., Sen, R., Barman, A., \& Khatun, M. R. (2020). Liming effects of poultry litter derived biochar on soil acidity amelioration and maize growth. Ecotoxicology and Environmental Safety, 202, 110-865, https://doi.org/10.1016/j.ecoenv.2020.110865.

Padilla, E. R. D., Santos, L. R. O., da Silva, D. A., Barros, J. L., Belini, G. B., Yamaji, F. M., Souza, T. M., \& Campos, C. I. (2019). Eucalyptus bark charcoal: The influence of carbonization temperature in thermal behavior. Materials Research., 22, 1-5, https://doi.org/10.1590/1980-5373-MR-2019-0371.

Parente, T. L., Lazarini, E., Caioni, S., de Souza, L. G. M., Pivetta, R. S., \& Bossolani, J. W. (2016). Potassium as topdressing in maize and the residual effects on soybean grown in succession, Rev. Agroambiente On-line, 10, 193-200, http://dx.doi.org/10.18227/1982-8470ragro.v10i3.3258.

Pariyar, P., Kumari, K., Jain, M. K., \& Jadhao, P. S. (2020). Evaluation of change in biochar properties derived from different feedstocks and pyrolysis temperature for environmental and agricultural application. Science of The Total Environment, 713, 136-433, https://doi.org/10.1016/j.scitotenv.2019.136433.

Pereira, M. E., Varanda, L. D., Nakashima, G. T., Hansted, A. L. S., da Silva, D. A., Tomeleri, J. O. P., Belini, G. B., \& Yamaji, F. M. (2019). Characterization of the poultry litter biomass for production of biochar. Rev. Virtual Quím., 11, 1330-1343, https://doi.org/10.21577/1984-6835.20190092.

Pereira, A. S., Shitsuka, D. M., Parreira, F. J., \& Shitsuka, R. (2018). Metodologia da Pesquisa Científica. [free e-book]. Santa Maria: UAB/NTE/UFSM. https://repositorio.ufsm.br/bitstream/handle/1/15824/Lic_Computacao_Metodologia-Pesquisa-Cientifica.pdf?sequence=1

Rogeri, D. A., Ernani, P. R., Mantovani, A., \& Lourenço, K. S. (2016). Composition of poultry litter in southern Brazil, Rev. Bras. Ciênc. Solo., 40, 140-697, https://doi.org/10.1590/18069657rbcs20140697.

Shepherd, E. M., airchild, B. D., \& Ritz, FC. W. (2017). Alternative bedding materials and litter depth impact litter moisture and footpad dermatitis. Journal of Applied Poultry Research., 26, 518-528, https://doi.org/10.3382/japr/pfx024.

Siefert, R. L., Scudlark, J. R., Potter, A. G., Simonsen, K. A., \& Savidge, K. B. (2004). Characterization of atmospheric ammonia emissions from a commercial chicken house on the Delmarva Peninsula. Environ. Sci. Technol., 38, 2769-2778, https://doi.org/10.1021/es0345874.

Song, W. \& Guo, M. (2012) Quality variations of poultry litter biochar generated at different pyrolysis temperatures. J. Anal. Appl. Pyrolysis, 94, 138-145, https://doi.org/10.1016/j.jaap.2011.11.018.

Speratti, A. B., M. S. Johnson, H. M. Sousa, G. M., \& Torres, E. G. Couto, (2017). Impact of different agricultural waste biochars on maize biomass and soil water content in a brazilian cerrado arenosol, Agronomy. 7 49, https://doi.org/10.3390/agronomy7030049.

Sweeten, J. M., Annamalai, K., Thien, B., \& McDonald, L. A. (2003). Co-firing of coal and cattle feedlot biomass (FB) fuels. Part I. Feedlot biomass (cattle manure) fuel quality and characteristics. Fuel, 82, 1167-1182, https://doi.org/10.1016/S0016-2361(03)00007-3.

Tańczuk, M., Junga, R., Werle, S., Chabiński, M., \& Ziółkowskic, Ł. (2019). Experimental analysis of the fixed bed gasification process of the mixtures of the chicken manure with biomass. Renewable Energy, 136, 1055-1063, https://doi.org/10.1016/j.renene.2017.05.074.

Tripathi, N., Hills, C. D., Singh, R. S., \& Atkinson, C. J. (2019). Biomass waste utilization in low-carbon products: harnessing a major potential resource. Climated and Atmosperic Science, 2, 35, https://doi.org/10.1038/s41612-019-0093-5.

Usmani, Z., Sharma, M., Awasthi, A. K., Sivakumar, N., Lukk, T., Pecoraro, L., Thakur, V. K., Roberts, D., Newbold, J., \& Gupta, V. K. (2021). Bioprocessing of waste biomass for sustainable product development and minimizing environmental impact. Bioresource Technology, 322, 124-548, https://doi.org/10.1016/j.biortech.2020.124548. 
Research, Society and Development, v. 10, n. 11, e351101119704, 2021

(CC BY 4.0) | ISSN 2525-3409 | DOI: http://dx.doi.org/10.33448/rsd-v10i11.19704

Vieites, F. M., Araújo, G. M., do Vale, P. A. C. B., Souza, C. S., Névoa, M. L., de Vargas Junior, J. G., Nunes, R. V., \& Arruda, N. V. M., (2015). Minerals balance and performance of broilers at 21 days of age diet containing Solanum malacoxylon. Rev. Bras. Saúde Prod. Anim., 16, 535-543, https://doi.org/10.1590/S1519-99402015000300006.

Voss-Rech, D., Trevisol, I. M., Brentano, L., Silva, V. S., Rebelatto, R., Jaenisch, F. R. F., Okino, C. H., Mores, M. A. Z., Coldebella, A., Botton, S. A., \& Vaz, C. S. L. (2017). Impact of treatments for recycled broiler litter on the viability and infectivity of microorganisms. Veterinary Microbiology., 203, 308-314, https://doi.org/10.1016/j.vetmic.2017.03.020.

Wang, S., Dai, G., Yang, H., \& Luo, Z. (2017). Lignocellulosic biomass pyrolysis mechanism: a state-of-art review. Progress in Energy and Combustion Science, 62, 33-86, https://doi.org/10.1016/j.pecs.2017.05.004.

Waqas, M., Abduriazaiza, A. S., Miandad, R., Rehan, M., Barakat, M., \& Nizami, A. (2018). Development of biochar as fuel and catalyst in energy recovery technologies, Journal of Cleaner Production, 188, 477-488, https://doi.org/10.1016/j.jclepro.2018.04.017.

Yaashikaa, P. R., Kumar, P. S., Varjani, S., \& Saravanan, A. (2020). A critical review on the biochar production techniques, characterization, stability and applications for circular bioeconomy, Biotechnology Reports., 28, e00570, https://doi.org/10.1016/j.btre.2020.e00570.

Yu, X. \& Lu, S. (2020). Double effects of biochar in affecting the macropore system of paddy soils identified by high-resolution X-ray tomography. Science of the Total Environment, 720, 137-690, https://doi.org/10.1016/j.scitotenv.2020.137690.

Zdravkov, B., Cermák, J., Sefara, M., \& Janku, J. (2017). Pore classification in the characterization of porus materials: a perspective. Open Chemistry, 5, 385395, https://doi.org/10.2478/s11532-007-0017-9. 